\begin{tabular}{|c|c|c|c|c|c|c|c|c|}
\hline \multicolumn{3}{|c|}{$\begin{array}{l}\text { 2. To: (Receiving Organization) } \\
\text { LMHC Characterization Engineering }\end{array}$} & \multicolumn{2}{|c|}{$\begin{array}{l}\text { 3. From: (Originating Organization) } \\
\text { Characterization Engineering }\end{array}$} & \multicolumn{4}{|c|}{$\begin{array}{r}\text { 4. Related EDT No.: } \\
\qquad \text { N/A }\end{array}$} \\
\hline \multicolumn{3}{|c|}{$\begin{array}{l}\text { 5. Proj./Prog./Dept./Div.: } \\
\text { Characterization Project }\end{array}$} & \multicolumn{2}{|c|}{$\begin{array}{l}\text { 6. Design Authority/Design Agent/Cog. } \\
\text { GP Janicek/CG Linschooten/RN Dale }\end{array}$} & \multicolumn{4}{|c|}{$\begin{array}{r}\text { 7. Purchase Order No.: } \\
\text { N/A }\end{array}$} \\
\hline \multirow{2}{*}{\multicolumn{5}{|c|}{$\begin{array}{l}\text { 8. Originator Remarks: } \\
\text { Supporting document submitted for review and approval prior to release } \\
\text { This document encompasses the ETP, Functional Design Requirements and ABU. }\end{array}$}} & \multicolumn{4}{|c|}{$\begin{array}{r}\text { 9. Equip./Component No.: } \\
\text { N/A }\end{array}$} \\
\hline & & & & & \multicolumn{4}{|c|}{$\begin{array}{r}\text { 10. System/Bldg./Facility: } \\
200 \mathrm{G}\end{array}$} \\
\hline \multirow{3}{*}{\multicolumn{3}{|c|}{$\begin{array}{l}\text { 11. Receiver Remarks: } \\
\text { ETN-99-0009 }\end{array}$}} & \multirow{3}{*}{\multicolumn{2}{|c|}{ e Document? [X] Yes [] No }} & \multicolumn{4}{|c|}{$\begin{array}{r}\text { 12. Major Assm. Dwg. No.: } \\
\text { N/A }\end{array}$} \\
\hline & & & & & \multicolumn{4}{|c|}{$\begin{array}{l}\text { 13. Permit/Permit Application No.: } \\
\text { N/A }\end{array}$} \\
\hline & & & & & \multicolumn{4}{|c|}{$\begin{array}{l}\text { 14. Required Response Date: } \\
\text { ASAP }\end{array}$} \\
\hline 15. & \multicolumn{4}{|c|}{ DATA TRANSMITTED } & (F) & (G) & $(H)$ & (l) \\
\hline $\begin{array}{l}\text { (A) } \\
\text { Item } \\
\text { No. }\end{array}$ & (B) Documentidrawing No. & $\begin{array}{l}\text { (C) } \\
\text { Sheet } \\
\text { No. }\end{array}$ & $\begin{array}{l}\text { (D) } \\
\text { Rev. } \\
\text { No. }\end{array}$ & (E) Title or Description of Data Transmitted & $\begin{array}{c}\text { Approval } \\
\text { Desig- } \\
\text { nator }\end{array}$ & $\begin{array}{l}\text { Reason for } \\
\text { Trans- } \\
\text { mittal }\end{array}$ & $\begin{array}{l}\text { Origi- } \\
\text { nator } \\
\text { Dispo- } \\
\text { sition }\end{array}$ & $\begin{array}{l}\text { Receiv- } \\
\text { er } \\
\text { Dispo- } \\
\text { sition }\end{array}$ \\
\hline 1 & RPP-5348 & $\mathrm{N} / \mathrm{A}$ & 0 & $\begin{array}{l}\text { ENGINEERING TASK PLAN FOR } \\
\text { WATER SUPPLY FOR SPRAY } \\
\text { WASHERS ON THE SUPPORT } \\
\text { TRUCKS. }\end{array}$ & $S / Q$ & 1 & 1 & \\
\hline
\end{tabular}

\begin{tabular}{|c|c|c|c|c|}
\hline \multicolumn{5}{|c|}{ KEY } \\
\hline Approval Designator (F) & & Reason for Transmittal (G) & & tion $\langle\mathrm{H}\rangle \&(\mathrm{l})$ \\
\hline $\begin{array}{l}\text { E, S, Q, D or N/A } \\
\text { (see WHC-CM-3-5, } \\
\text { Sec.12.7) }\end{array}$ & $\begin{array}{l}\text { 1. Approval } \\
\text { 2. Release } \\
\text { 3. Information }\end{array}$ & $\begin{array}{l}\text { 4. Review } \\
\text { 5. Post-Review } \\
\text { 6. Dist. (Receipt Acknow. Required) }\end{array}$ & $\begin{array}{l}\text { 1. Approved } \\
\text { 2. Approved w/comment } \\
\text { 3. Disapproved wicomment }\end{array}$ & $\begin{array}{l}\text { 4. Reviewed no/comment } \\
\text { 5. Reviewed w/comment } \\
\text { 6. Receipt acknowledged }\end{array}$ \\
\hline
\end{tabular}

(See Approval Designator for required signatures)

\begin{tabular}{|c|c|c|c|c|c|}
\hline $\begin{array}{l}\text { (G) } \\
\text { Rea- } \\
\text { Son }\end{array}$ & $\begin{array}{l}\text { (H) } \\
\text { Disp. }\end{array}$ & $\begin{array}{lll}\text { (J) Name } & \text { (K) Signature (L) Date (M) MSIN }\end{array}$ & $\begin{array}{l}\text { (G) } \\
\text { Rea- } \\
\text { son }\end{array}$ & $\begin{array}{c}\text { (H) } \\
\text { Disp. }\end{array}$ & $\begin{array}{llll}\text { (J) Name } & \text { (K) Signature (L) Date } & \text { (M) MSIN }\end{array}$ \\
\hline 1 & 1 & Design Authority GP Janic & 1 & 1 & RM Boger $2>3 \times 9-2 / 3 / 02$ \\
\hline 1 & 1 & Design Agent CG Lins & 1 & 1 & 72.2 .0057 .03 \\
\hline 1 & 1 & Cog.Eng. RN Dales & 1 & 1 & JL Smalley 11 \&mallen $2 / 2 / \infty 7-12$ \\
\hline 1 & 1 & Cog. Mgr. JS Schofield $2 / 2 / 100$ S7-12 & 3 & & M.R.KEMBEL O \\
\hline 1 & 1 & QA ML McElror M.P. $M^{4}\left\{\mathrm{Sm}^{1.17 .00} 57-07\right.$ & 3 & & B.L. COVER DELL \\
\hline 1 & 1 & Safety $C D$ Jackson $C . D$ & & & \\
\hline & & Env. & & & \\
\hline
\end{tabular}

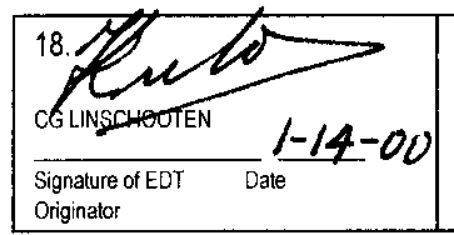

BD-7400-172-2 (05/96) GEF097
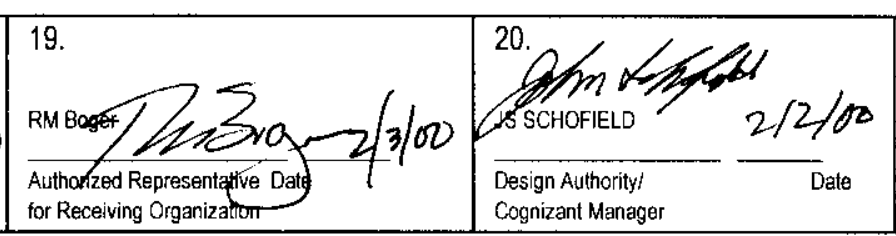

21. DOE APPROVAL (if required) Ctrl. No.

[] Approved

[] Approved w/comments

[] Disapproved w/comments 


\title{
ENGINEERING TASK PLAN FOR WATER SUPPLY FOR SPRAY WASHERS ON THE SUPPORT TRUCKS
}

\author{
R.M. Boger \\ Prepared by CH2M HILL Hanford Group, Inc. \\ Richland, WA 99352 \\ U.S. Department of Energy Contract DE-AC06-96RL13200

$\begin{array}{lll}\text { EDT/ECN: } & 627882 & \text { UC: } 2000 \\ \text { Org Code: } & 74900 & \text { Charge Code: } 102206 E S 10 \\ \text { B\&R Code: } & \text { EW313000 } & \text { Total Pages: } / 9\end{array}$

Key Words: RMCS, SUPPORT TRUCKS, WATER SUPPLY, DRILL ROD, SPRAY WASHERS, TANK FARM, CHARACTERIZATION PROJECT, ETN-99-0009.

Abstract: This ETP defines the task and deliverables associated with the design, fabrication and testing of an improved spray wash system for the Rotary Mode Core Sampling (RMCS) System Support Trucks.

TRADEMARK DISCLAIMER. Reference herein to any specific commercial product, process, or service by trade name trademark, manufacturer, or otherwise, does not necessarily constitute or imply its endorsement, recommendation, or favoring by the United States Government or any agency thereof or its contractors or subcontractors.

Printed in the United States of America. To obtain copies of this document, contact: Document Control Services, P.O. Box 950, Mailstop H6-08, Richland WA 99352, Phone (509) 372-2420; Fax (509) 376-4989.
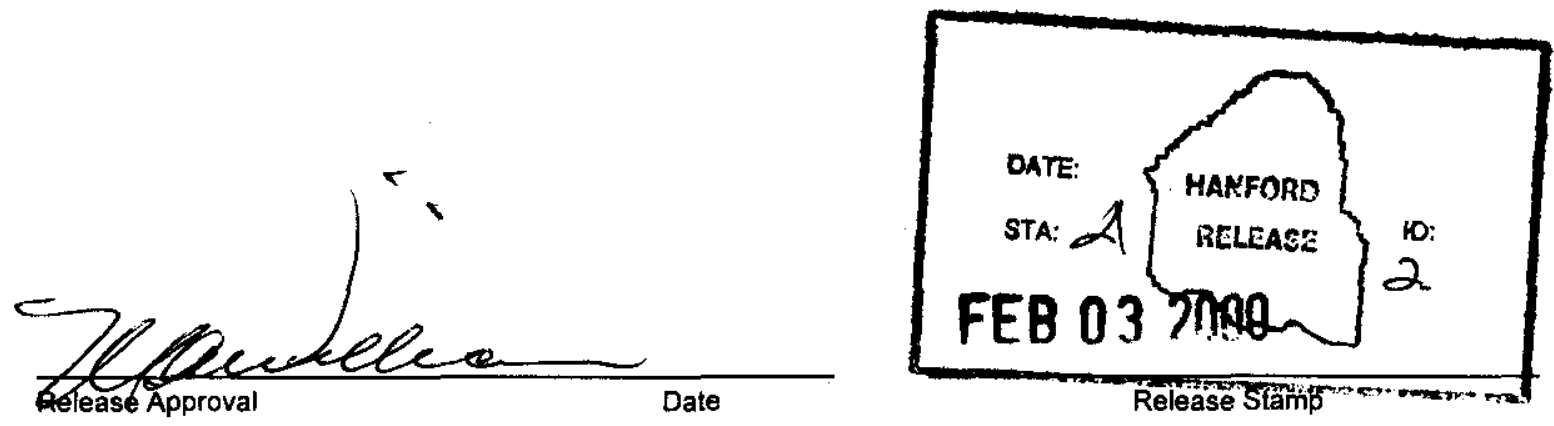

\section{Approved For Public Release}


RPP-5348

Rev.0

\title{
ENGINEERING TASK PLAN FOR WATER SUPPLY FOR SPRAY WASHERS ON THE SUPPORT TRUCKS
}

\author{
Characterization Engineering \\ River Protection Project \\ $\mathrm{CH} 2 \mathrm{M}$ HILL Hanford Group, Inc. \\ Richland, Washington
}

Prepared by

C. G. Linschooten

Numatec Hanford Corporation

Richland, Washington

February 2000 
Table of Contents

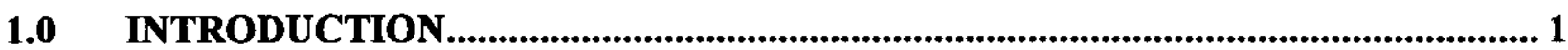

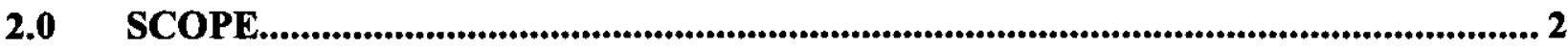

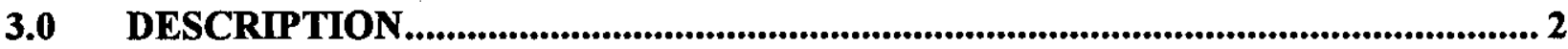

3.1 PHYSICAL DESCRIPTION .......................................................................................... 2

3.2 DESIGN REQUIREMENTS ........................................................................................ 2

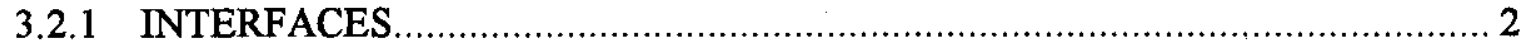

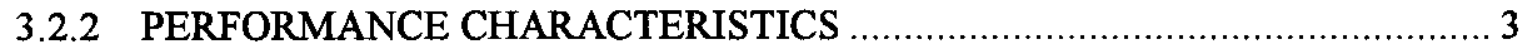

3.2.3 PHYSICAL CHARACTERISTICS ....................................................... 4

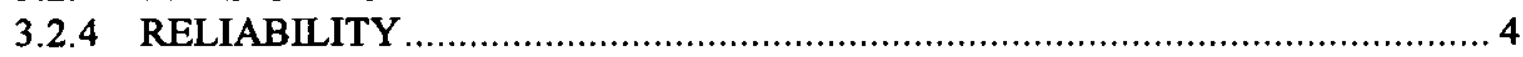

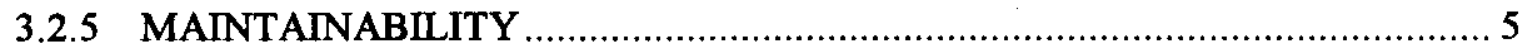

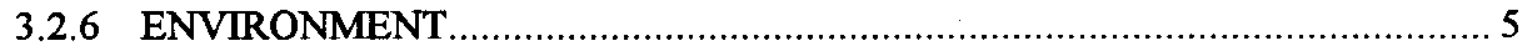

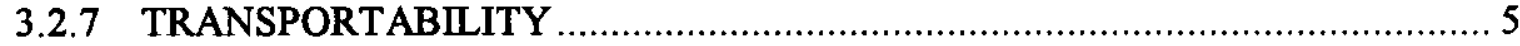

3.3 ENGINEERING TASKS ............................................................................................. 5

3.3.1 DESIGN.

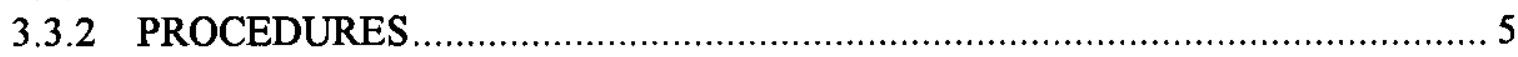

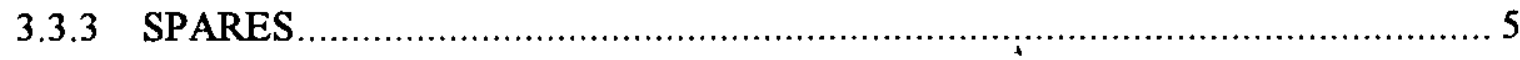

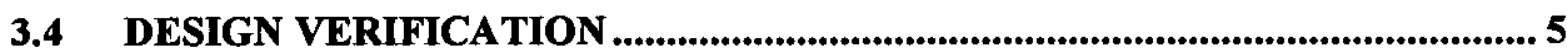

3.5 PROCUREMENT/FABRICATION TASKS....................................................6

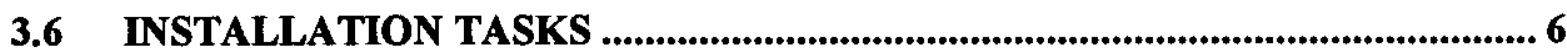

3.7 PRE-OPERATIONAL AND OPERATIONAL TESTS ........................................ 6

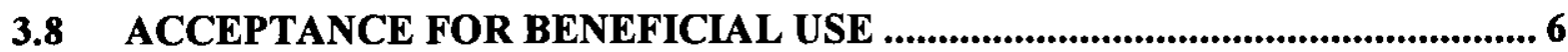

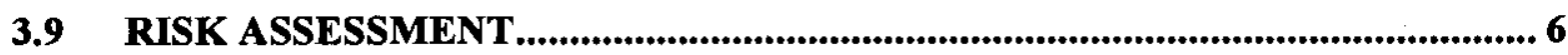

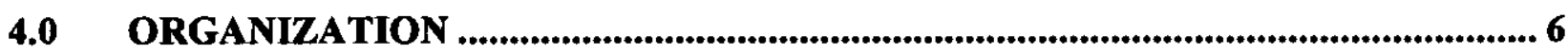

4.1 CHARACTERIZATION FIELD ENGINEERING (CFE) ................................... 6

4.2 CHARACTERIZATION ENGINEERING ....................................................... 6

4.3 CHARACTERIZATION PROJECT OPERATIONS............................................ 7

4.4 QUALITY ASSURANCE AND SAFETY .......................................................... 7 


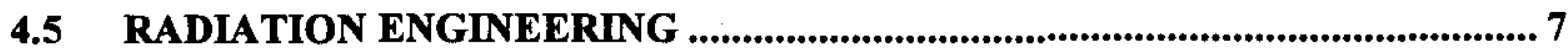

4.6 FLAMMABLE GAS EQUIPMENT ADVISORY BOARD ................................ 7

5.0 SCHEDULE AND COST ESTIMATE

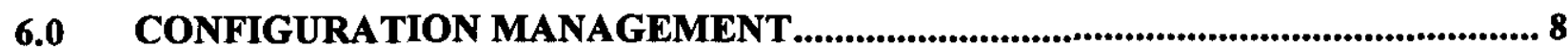

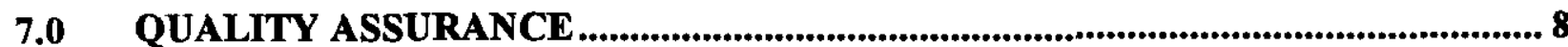

8.0 SAFETY AND AUTHORIZATION BASIS .......................................................... 8

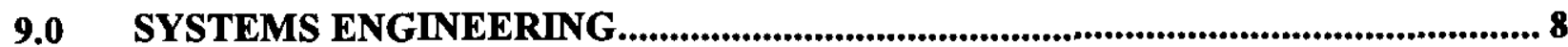

10.0 CLOSEOUT COSTS

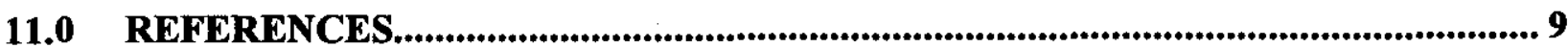

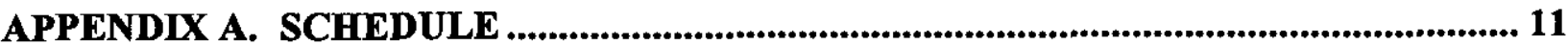

APPENDIX B. COLD WEATHER OPERATING PARAMETERS ................................ 13

APPENDIX C. ACCEPTANCE FOR BENEFICIAL USE .......................................... 14 
RPP-5348

Rev.0

\section{ENGINEERING TASK PLAN FOR WATER \\ SUPPLY FOR SPRAY WASHERS \\ ON SUPPORT THE TRUCKS}

\subsection{INTRODUCTION}

When sampling equipment is removed from waste storage tanks by the core drilling truck, the components are washed. Washing is performed with one of four spray washers depending upon the component being removed:

1. The Cable Spray Washer P/N H-2-690134-11 (LMHC 1996) cleans the sampler hoist cable as it is withdrawn from the drill string carrying the Remote Latch Unit (RLU) and sampler. It also cleans the grapple hoist cable as it is withdrawn from the drill string carrying the pintle rod and grapple. The Cable Spray Washer washing fluid is supplied at a maximum pressure of $400 \mathrm{psig}$.

2. The Riser Sleeve P/N H-2-690134-14 (LMHC 1996) has an array of washer nozzles at its bottom to wash the drill rod as it is pulled out of the tank after sampling is complete. The washing fluid for the riser sleeve washer has a maximum pressure of 1200 psig.

3. The Drill Rod Washer Manifold P/N H-2-690134-17 (LMHC 1996) washes the drill rod a second time as it is pulled out of the tank. (The drill rod may be washed twice since it was in direct contact with the waste and will be the most contaminated.) The washing fluid for the drill rod washer has a maximum pressure of $400 \mathrm{psig}$.

4. The Riser Sleeve Spray Washer P/N H-2-690134-15 (LMHC 1996) cleans the riser sleeve as it is taken out of the riser after sampling is complete. The washing fluid for the riser sleeve spray washer has a maximum pressure of $400 \mathrm{psig}$.

The tank and pump that supply washing fluid (.3 molar lithium bromide and water solution) to the spray wash equipment are located on a support truck. Several shortcomings have been reported in the current design:

1. The pump is located above the supply tank. The pump has insufficient suction (rated at 24 inches) to empty the tank.

2. The truck is used for hauling miscellaneous sampling equipment in addition to the washing equipment.

3. Reliability problems have been reported with the tank level switch. Also, freezing of the equipment/pump in the winter has been problematical.

A design will be undertaken that will utilize a pump and a custom-built storage tank. The pump will be located below the tank to ensure positive pressure to the pump inlet. 
The pump inlet plumbing shall consist of fittings at least as big as the pump inlet. In the discharge plumbing fittings smaller than the pump outlet will not be allowed.

\section{$2.0 \quad$ SCOPE}

This Engineering Task Plan addresses all activities associated with the design, fabrication, and testing of an improved spray wash system for core sampling operations, that will be located on the Service Trucks.

\subsection{DESCRIPTION}

\subsection{PHYSICAL DESCRIPTION}

The spray wash system will consist of an enlarged supply tank and an 8 GPM pump set at 1200 psig. The pump will be located at a level below the supply tank so that the fluid will easily run into the pump inlet with a minimum of suction head. The connection from the supply tank to the pump inlet will be designed with a minimum of headloss. The system will pump a lithium bromide $(\mathrm{LiBr})$ tracer solution.

Note: The existing pump is made of forging brass (Type: 37700 ), which is prone to deteriorate in the .3 molar $\mathrm{LiBr}$. solution. All parts and, in this case the pump, will be made of stainless steel. No aluminum or brass will be used when handling a solution of water with .3 molar LiBr. See letter reports: 74A40-96-RPA-005 (Anantatmula 1996a); 74A40-96-RPA-008, (Anantatmula 1996b); 74A40-96-RPA-011 (Anantatmula 1996c); 74A40-96-RPA-012 (Anantatmula 1996d); and 74A40-96-RPA-017(Anantatmula 1996e)

\subsection{DESIGN REQUIREMENTS}

Design criteria shall be prepared and documented per RPP-PRO-1819 (LMHC 1998). The Design Compliance Matrix will be updated per Characterization Project Desk Instruction DI-CE-008-01 (Boger, R.M. 1999a). The applicable Authorization Basis (AB) documents for the system are HNF-SD-WM-SAR-067 "TWRS Final Safety Analysis Report," (HNF, 1999). HNF-SD-WM-TSR-006 (HNF, 1999a) and WHC-SD-WM-SAD035, Rev.0-b (LMHC 1997). The applicable design standard for electrical equipment shall be NFPA 70, the National Electric Code.

The overall safety class shall be General Service (GS).

\subsubsection{INTERFACES}

Spray washer power supply. The electrical power shall be compatible with the existing electrical system. The spray wash system is supplied with electrical power from an electrical distribution trailer, see drawings H-2-85340 (LMHC 1994) and H-2-85341 (LMHC 1994a).

Filling of the tank. The tanks are filled by hand with four gallon bottles. Easy access shall be provided for this operation.

The tank fill opening shall be accessible by an operator without the use of ladders or stairs. 
Winterizing supplies and support. To minimize the damage due to freezing the equipment shall be able to be winterized.

\subsubsection{PERFORMANCE CHARACTERISTICS}

3.2.2.1 The pump and tank system shall be constructed as a single module that can be installed and removed as a unit. The module shall include: the tank, pump, electrical switch gear, plumbing, and controls. The hoses with the reels are not included in this module and are permanently mounted on the support truck.

3.2.2.2 The pump shall be mounted in such a way that it will be easy to install and remove mechanical and electrical components.

3.2.2.3 The spray wash system shall fit into the bed of any of the support trucks and be able to be lifted in and out of the support trucks with the aid of a crane.

3.2.2.4 The spray wash system shall be able to be lifted with a hoist when the tank is full with water.

3.2.2.5 The entire system shall be designed to handle a solution of $130^{\circ} \mathrm{F}$ water with .3 molar $\mathrm{LiBr}$.

3.2.2.6 The tank or drum shall have a pumping volume of 80 gallons minimum and still have a minimum expansion volume of 10 percent in case the water freezes.

3.2.2.7 The entire spray wash system shall be protected from freezing.

3.2.2.8 The tank shall be designed to be freeze and thaw resistant.

3.2.2.9 The pump pressure relief valve shall be set at $1200 \mathrm{psig}$.

3.2.2.10 The system shall be capable of measuring the volume of fluid used for washing, independent of the pump re-circulation.

3.2.2.11 The level cut-off switch shall be able to withstand the truck's road vibrations and freeze and thaw cycles without failing. The level switch shall be protected from external damage.

3.2.2.12 The system shall have a blowout manifold in order for the fluid to be purged from the pump and piping back into the tank.(3.2.2.7)

3.2.2.13 The pump and its accessories shall be protected from damage by other materials and equipment.

3.2.2.14 The heater in the tank shall be able to raise the temperature of the spray wash fluid (ref. 3.2.2.7) by $80^{\circ} \mathrm{F}$ in 2 hours. The estimated temperature rise is from $50^{\circ} \mathrm{F}$ to $130^{\circ} \mathrm{F}$. If a new heater is necessary, it shall be compatible with the existing electrical service. 
RPP-5348

Rev.0

3.2.2.15 The system shall be capable of maintaining the water at $130^{\circ} \mathrm{F}+/-10^{\circ} \mathrm{F}$ at a minimum ambient operating temperature of $20^{\circ} \mathrm{F}$.

3.2.2.16 The system shall have a temperature indication of $+/-2^{\circ} \mathrm{F}$ for the fluid.

3.2.2.17 The pump discharge shall be divided into two supply lines. One shall supply spray wash fluid at $1200 \mathrm{psig}$ and one shall supply spray wash fluid at $400 \mathrm{psig}$.

\subsubsection{PHYSICAL CHARACTERISTICS}

3.2.3.1 All handles, switches, and connections that must be operated or mated in the field must be operable by a person wearing the appropriate personnel protective equipment.

3.2.3.2 A strainer shall be installed on the inlet side of the pump. A vacuum gage connection shall be installed that can be used to assess system operation.

3.2.3.3 The tank shall be vented to the atmosphere.

3.2.3.4 The tank shall have an 8-inch diameter fill opening on top.

3.2.3.5 The tank shall have baffles in it to minimize the movement of the fluid during transport.

3.2.3.6 The tank outlet to the pump shall be positioned $1 / 2$ inch off the bottom of the tank.

3.2.3.7 The tank shall be made of stainless steel.

3.2.3.8 The return line for the fluid at the pump discharge pressure relief valve shall be routed back to the tank.

3.2.3.9 The system shall have a low tankfluid level cut-off switch to protect the heater and the pump from operating dry.

3.2.3.10 Two extra 25 foot long pressure hoses shall be supplied. These hoses will be used if an extension is needed.

3.2.3.11 A drain shall be placed in the lowest practical position in the tank.

3.2.3.2 All gauges shall be oriented for ease of reading.

3.2.3.3 The tank fill cover shall be easily opened and closed.

\subsubsection{RELIABILITY}

3.2.4.1 If the spray wash system is not freeze damaged or the pump allowed to run dry, the system shall be capable of being operated for at least 2000 hours before requiring replacement. The system shall be capable of being started at least 5000 times. 
3.2.4.2 The spray wash system shall operate reliably when exposed to summer heat $\left(110^{\circ} \mathrm{F}\right)$, winter cold $\left(20^{\circ} \mathrm{F}\right)$ and high winds $(45 \mathrm{mph})$ with blowing dust.

\subsubsection{MAINTAINABILITY}

3.2.5.1 All components shall be designed to the maximum practical extent to facilitate decontamination. The components shall be designed to be blown out and/or drained completely.

3.2.5.2 All parts shall be able to be reached easily for field maintenance.

\subsubsection{ENVIRONMENT}

3.2.6.1 The components of the system shall be able to withstand storage temperature extremes from $10^{\circ} \mathrm{F}$ to $120^{\circ} \mathrm{F}$.

3.2.6.2 The system shall withstand severe weather including freezing rain, rain, snow, intense direct sunlight, winds to $70 \mathrm{mph}$, and blowing sand and dust.

\subsubsection{TRANSPORTABILITY}

3.2.7.1 The system must be capable of being transported on site with any of the core sampler support trucks. The system shall be mounted on a skid. The skid shall fit in the bed of the core sampler support trucks. If the system gets too big for the core sampler support trucks, it can be mounted on a trailer with Operations written concurrence.

\subsection{ENGINEERING TASKS}

The engineering tasks contained in this task plan are the minimum necessary activities to provide a water supply system for the core sampling spray washers that is safe to deploy in the RPP tank farm facilities. The overall task is to design, build, and test a system that will meet the functions and requirements identified in this ETP. Characterization Engineering (CE) will complete the engineering tasks.

\subsubsection{DESIGN}

The design will be documented per LMH-PRO-1819 (LMHC 1998).

\subsubsection{PROCEDURES}

Operation and maintenance procedures will be prepared and/or revised as required to support the operation and the maintenance of the new spray wash fluid supply system.

\subsubsection{SPARES}

A list of recommended spare parts will be provided for the spray wash fluid supply system.

\subsection{DESIGN VERIFICATION}

Independent design verification will be performed in accordance with HNF-IP-0842, Volume IV, Section 4.24 "Design Verification" (LMHC 1998a) prior to release of the 
RPP-5348

Rev.0

design drawings. Design reviews will be conducted per LMH-PRO-1819 (LMHC 1998). The safety classification of the RMCS Support Trucks is General Service (GS).

\subsection{PROCUREMENT/FABRICATION TASKS}

Procurement activities will be performed by Characterization Project Operations (CPO).

Vendor proposals will go through a preliminary design review prior to award of the fabrication contract. The design will go through a final design review prior to fabrication.

\subsection{INSTALLATION TASKS}

The system will be designed to be portable. The initial installation will be completed by the organization that will operate the system, CPO.

\subsection{PRE-OPERATIONAL AND OPERATIONAL TESTS}

Testing will be documented and conducted per HNF-IP-0842, Volume IV, section 4.28 “Testing Practices Requirements" (LMHC 1998a). A test report will be issued to document the results of acceptance and operational testing performed.

\subsection{ACCEPTANCE FOR BENEFICIAL USE}

An Acceptance for Beneficial Use (ABU) will be developed per HNF-IP-0842, Volume IV, Section 3.12, "Acceptance of Structures, Systems and Components for Beneficial Use" (LMHC 19998a), and Characterization Project Desk Instruction, DI-CP-004-02, "Acceptance for Beneficial Use (ABU)" (Boger, R.M. 1999). The ABU is included as an Appendix to this ETP.

\subsection{RISK ASSESSMENT}

No potential risk can be identified to complete this task. Characterization Engineering and $\mathrm{CPO}$ are in concurrence to complete this task and the funding is available.

\subsection{ORGANIZATION}

\subsection{CHARACTERIZATION FIELD ENGINEERING (CFE)}

CFE will provide Cognizant Engineer support as required for this task. CFE will prepare or revise all operating and maintenance procedures, as required, to support the deployment of the new system.

Cognizant Manager: J. S. Schofield Cognizant Engineer: R. N. Dale

\subsection{CHARACTERIZATION ENGINEERING}

Characterization Engineering (CE) will provide Design Authority support for this task. CE personnel will prepare all documentation associated with the development of the design requirements, procurement specifications, and fabrication and testing of the new system. CE personnel and the cognizant engineer will witness all testing, and the Design Authority will approve the results of all testing. 
Design Authority: G. P. Janicek

Project Manager: J. L. Smalley

Responsible Engineer: C. G. Linschooten

\subsection{CHARACTERIZATION PROJECT OPERATIONS}

Characterization Project Operations (CPO) will provide review of specifications and procedures associated with this task. The logistics of performing on-site testing will be the responsibility of $\mathrm{CPO}$ with the support of $\mathrm{CE} / \mathrm{CFE}$.

Operations Manager: M. R. Kembel

Core Sampling Manager: J. S. Lee

\subsection{QUALITY ASSURANCE AND SAFETY}

CH2M HILL Hanford Group, Inc. (CHG) will provide Quality Assurance (QA) and Safety support. QA and Safety will participate in the review of design, specification, and testing documents, witness testing as specified in the test procedures, and approve test results as required by HNF-IP-0842, Volume XI, Section 1.1 "Quality Assurance Program" (LMHC 1998a), and HNF-IP-0842, Volume IX, Section 1.1 "RPP Safety Program Plan", (LMHC 1998a).

QA Engineer: M. L. McElroy

Safety Engineer: C. D. Jackson

\subsection{RADIATION ENGINEERING}

Not applicable.

\subsection{FLAMMABLE GAS EQUIPMENT ADVISORY BOARD}

Not applicable.

\subsection{SCHEDULE AND COST ESTIMATE}

The CPE Project Manager will maintain a detailed schedule for all tasks. A rough schedule is included in Appendix A. The scheduled completion of this task will be affected by the priorities assigned by $\mathrm{CE}$ and $\mathrm{CPO}$ based upon project commitments.

Estimated Cost:

Engineering

Procurement

1200-hrs

$\$ 25 \mathrm{k}$

Fabrication

$\$ 50 \mathrm{k}$

Engineering expenses will be charged to Cost Account Charge Number (CACN)102250/Code of Accounts (COA) B000. Quality Assurance, Safety, RADCON will also be charged to CACN 102250 for this task. CPO and maintenance expenses are funded separately. 


\subsection{CONFIGURATION MANAGEMENT}

The design of the system will be documented. Standard H-series drawings will be created to document the configuration, and Essential and Support drawings will be assigned as required by LMH-PRO-1819 (LMHC 1998). A vendor information file will be established per LMH-PRO1819 (LMHC 1998), to contain catalog cuts, performance specifications, and/or installation/operation instructions for components or systems supplied by the manufacturer. All modifications made to standard manufacturer products will be documented on $\mathrm{H}-2$ series drawings.

\subsection{QUALITY ASSURANCE}

All work associated with this task will be in compliance with HNF-IP-0842, Volume XI, Quality Assurance Program, Section 1.1. QA oversight will be provided as defined in this ETP.

\subsection{SAFETY AND AUTHORIZATION BASIS}

All work associated with this task will be in compliance with HNF-IP-0842, Volume IX, "RPP Safety Program Plan" (LMHC 1998). The Authorization Basis for the system will be HNF-SD-WM-SAR-067, "TWRS Final Safety Analysis Report" (HNF 1999), HNF-SD-WMTSR-006 (HNF 1999a), and WHC-SD-WM-SAD-035 (LMHC 1997). The applicable industry safety standards will be considered for all safety concerns associated with this task. The Unreviewed Safety Question (USQ) process will be used as required per HNF-IP-0842, Volume IV, Section 5.4 "Unreviewed Safety Questions" of LMHC 1998.

\subsection{SYSTEMS ENGINEERING}

This activity is necessary to support the characterization of the waste in the underground waste storage tanks on the Hanford Site. This activity supports the Tank Farms task identified in the Work Breakdown Structure (WBS) as task number 1.1.1.1.1.3.1.9, Core Sampling Systems.

\subsection{CLOSEOUT COSTS}

If the task is no longer required, an estimate will be prepared before the closure of the task. The amounts of all outstanding purchase agreements will be included as closeout costs. 


\subsection{REFERENCES}

Boger, R. M., 1999, “Acceptance for Beneficial Use (ABU)," Characterization Project Desk Instruction, DI-CP-004-02, Lockheed Martin Hanford Corporation, Richland, Washington.

Boger, R. M., 1999a, "Design Compliance Matrix," Characterization Project Desk Instruction, DI-CE-008-01.

HNF, 1999, HNF-SD-WM-SAR-067, Rev 1C, “Tank Waste Remediation System Final Safety Analysis Report”(FSAR), January 1999, Lockheed Martin Hanford Corporation, Richland, Washington.

HNF, 1999a, HNF-SD-WM-TSR-006, Rev. 1B, "Tank Waste Remediation System Technical Safety Requirements," including Addendum, January 1999, Lockheed Martin Hanford Corporation, Richland, Washington.

LMHC, 1994, Drawing H-2-85340, Rev. 2, "Core Sampling Trailer One Line Diagrams" Lockheed Martin Hanford Corporation, Richland, Washington.

LMHC, 1994a, Drawing H-2-85341, Rev. 1, "Core Sampling Trailer DT-B - Electrical," Lockheed Martin Hanford Corporation, Richland, Washington.

LMHC, 1996, Drawing H-2-690134, Rev. 5 "Drill String Arrangements (RMCST)," Lockheed Martin Hanford Corporation, Richland, Washington.

LMHC, 1996a, Letter, R. P. Anantatmula to J. S. Schofield, "Transmittal of Report on Compatibility of Drill String Materials with $0.3 \mathrm{~m} \mathrm{LiBr}$ Solution," 74A40-96-RPA-005, March 19, 1996, Lockheed Martin Hanford Corporation, Richland, Washington.

LMHC, 1996b, Letter, R. P. Anantatmula to J. S. Schofield, "Transmittal of report on compatibility of $90 \%$ tungsten alloy with $0.3 \mathrm{M} \mathrm{LiBr}$ solution," 74A40-96-RPA-008, May 7, 1996, Lockheed Martin Hanford Corporation, Richland, Washington.

LMHC, 1996c, Letter, R. P. Anantatmula to J. S. Schofield, "Transmittal of report on compatibility of aluminum and brass with $0.3 \mathrm{M} \mathrm{LiBr}$ solution," 74A40-96-RPA-011, July 2, 1996, Lockheed Martin Hanford Corporation, Richland, Washington.

LMHC, 1996d, Letter, R. P. Anantatmula to J. S. Schofield, "Compatibility of Monel 400 with 0.3M LiBr Solution and Hanford Tank Wastes," 74A40-96-RPA-012, July 2, 1996, Lockheed Martin Hanford Corporation, Richland, Washington. 
LMHC, 1996e, Letter, R. P. Anantatmula to J. S. Schofield, "Transmittal of Report on Compatibility of Nickel 200, Monel 400 and Low Silicon Bronze with $0.3 \mathrm{M} \mathrm{LiBr}$

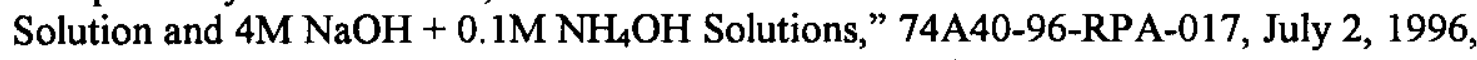
Lockheed Martin Hanford Corporation, Richland, Washington.

LMHC 1997, WHC-SD-WM-SAD-035, Rev. OB, “A Safety Assessment of Rotary-Mode Core Sampling in Flammable-Gas Single-Shell Tanks: Hanford Site, Richland, Washington, August 1997." Lockheed Martin Hanford Corporation, Richland, Washington.

LMHC, 1998, LMH-PRO-1819, latest revision, "Project Hanford Policy and Procedure System PHMC Engineering Requirements," Lockheed Martin Hanford Corporation, Richland, Washington.

LMHC, 1998a, HNF-IP-0842, "RPP Administration (Procedures, Policies, Plans and Waivers)," latest revision, Lockheed Martin Hanford Corporation, Richland, Washington. 
RPP-5348

Rev.0

Appendix A. Schedule 
RPP-5348

Rev.0

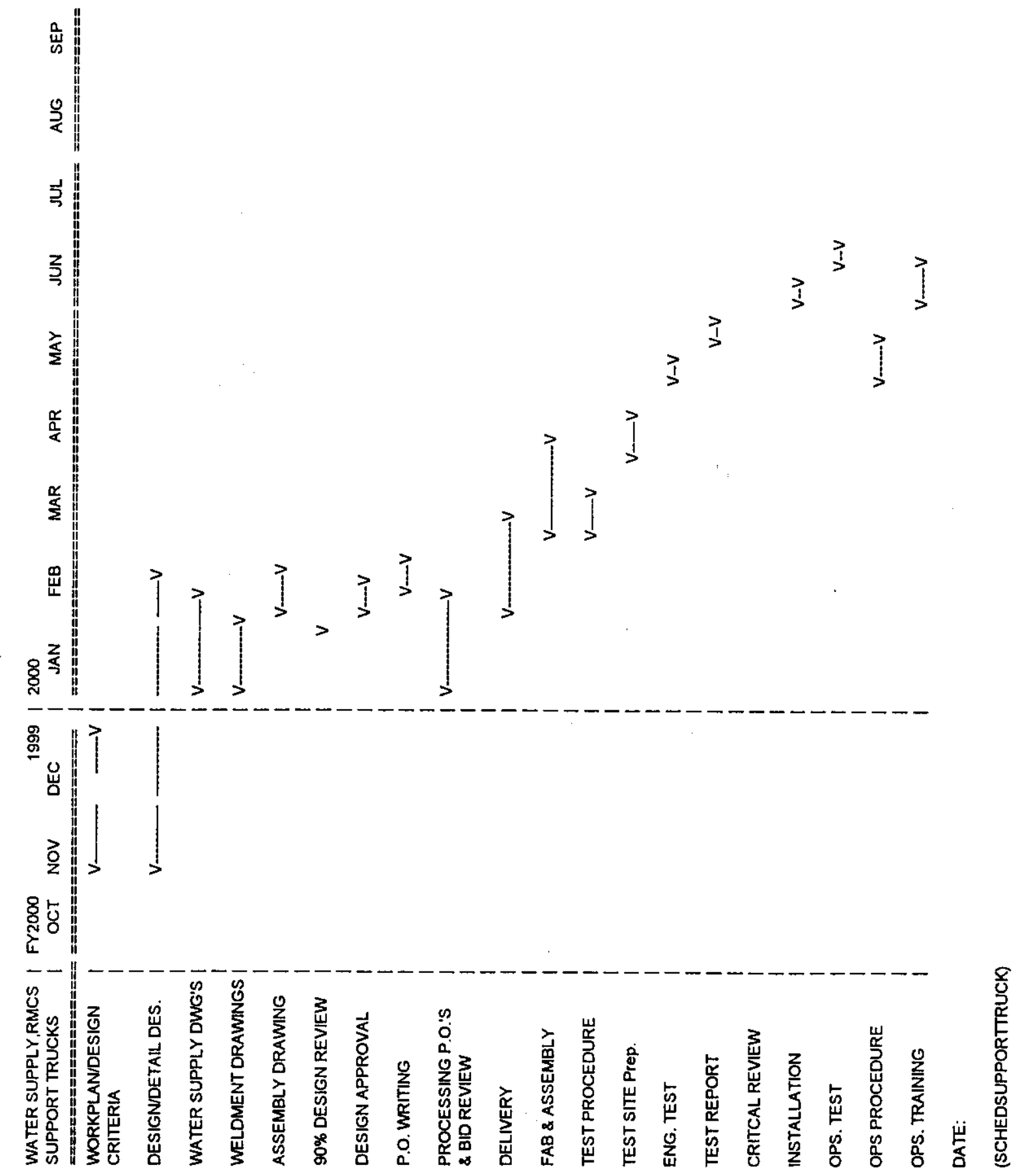

IIAP012\ACTLOGILinschootenIETP Support Trucka.doc 12 
Appendix B. Cold Weather Operating Parameters and Design Considerations.

Preliminary calculations indicate that, when electrical power is disconnected from the spray wash fluid supply system and the water is at $130^{\circ} \mathrm{F}$ in the tank, and the outside temperature is $0^{\circ} \mathrm{F}$, it takes approximately two days for the water to cool to $32^{\circ} \mathrm{F}$ and another four days to freeze solid in the tank. Hoses filled with $130^{\circ} \mathrm{F}$ water will most likely freeze solid in 8 to 12 hours. Therefore, all the hoses and the pump should be blown out after every shift, and the tank should be emptied when the tank is exposed to freezing conditions for longer than 3 days.

The tank and pump can be insulated with PVC foam panels to slow this process. The heater in the tank can be wired to accept 110 VAC. Powered by 110 VAC the heater puts out approximately 1900 watts and will keep the tank warm as long as the electric power is on and there is insulation. Alternately the tank and the pump can be heat traced to prevent freezing, which also requires electric power.

If the tank freezes solid, it is probable that the heater will be damaged. If the pump freezes, it will probably be ruined. If the hoses freeze, the integrity of the hoses might be lost. 
RPP-5348

Rev.0

APPENDIX C. ACCEPTANCE FOR BENEFICIAL USE 


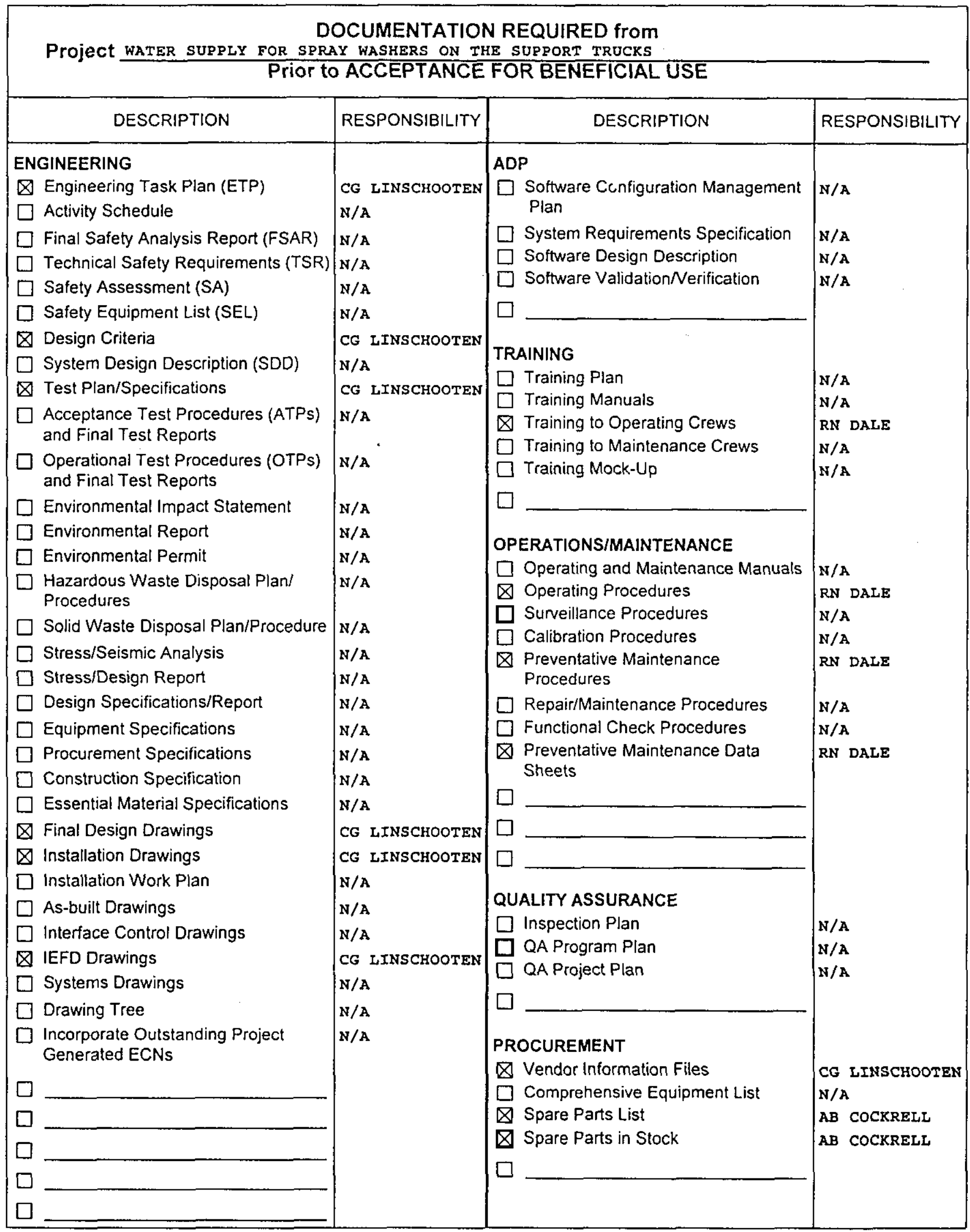

